\title{
Traumatic Gallbladder Perforation in Children - Case Report and Review
}

\section{Traumatische Gallenblasenperforationen bei Kindern - Fallbericht und Literaturübersicht}

Authors

Melanie Thanh Phuong Le ${ }^{1}$, Jochen Herrmann², Michael Groth ${ }^{2}$, Konrad Reinshagen ${ }^{1}$, Michael Boettcher ${ }^{1}$

Affiliations

1 Department of Paediatric Surgery, University Medical Center Hamburg-Eppendorf, Hamburg, Germany

2 Department of Diagnostic and Interventional Radiology and Nuclear Medicine, Section of Paediatric Radiology, University Medical Center Hamburg-Eppendorf, Hamburg, Germany

Key words

traumatic gallbladder injury in children, gallbladder perforation, handlebar injuries

received 26.05.2020

accepted 02.12 .2020

published online 03.02 .2021

Bibliography

Fortschr Röntgenstr 2021; 193: 889-897

DOI 10.1055/a-1339-1904

ISSN 1438-9029

(c) 2021. Thieme. All rights reserved.

Georg Thieme Verlag KG, Rüdigerstraße 14,

70469 Stuttgart, Germany

Correspondence

Dr. Michael Boettcher

Department of Paediatric Surgery, University Medical Center

Hamburg-Eppendorf, Martinistr. 52, 20246 Hamburg,

Germany

Tel.: +49/17 71978782

m.boettcher@uke.de

\section{ZUSAMMENFASSUNG}

Hintergrund Gallenblasenperforationen im Kindesalter sind sehr selten und einfach zu übersehen. Die klinischen und radiologischen Zeichen sind meist relativ unspezifisch. Entsprechend schwierig gestaltet sich die Diagnosestellung, sodass Gallenblasenverletzungen initial häufig übersehen werden mit potenziell fatalen Konsequenzen. Dieser Fallbericht mit Literaturübersicht sammelt die Kernessenzen hinsichtlich Diagnostik und Therapie dieses seltenen Krankheitsbildes.

Methode Wir stellen den Fall eines 8-jährigen Jungen nach stumpfem Bauchtrauma durch einen Fahrradlenker vor, in welchem bildgebende Verfahren, in unserem Falle Sonografie und Magnetresonanztomografie, ausschlaggebend für die richtige Therapie waren. Eine ergänzende Literaturrecherche vergleicht ähnliche Fallberichte mit isolierter Gallenblasenperforation bei Kindern. PubMed und Google Scholar wurden unter den Schlüsselbegriffen „gallbladder injury in children“, „gallbladder perforation children“, „blunt abdominal trauma children“ durchsucht. In die Recherche wurden ausschließlich pädiatrisch zentrierte Artikel mit Publikationsdatum zwischen 2000 und 2020 eingeschlossen, um möglichst einen zeitgemäßen Überblick zu gewährleisten.

Ergebnisse und Schlussfolgerung Gallenblasenperforationen bei pädiatrischen Patienten lassen sich in der aktuellen Literatur nur spärlich finden. Nur 8 vergleichbare Fälle konnten im oben genannten Zeitraum identifiziert werden. Da Symptome häufig verzögert und unspezifisch auftreten, spielen bildgebende Verfahren in der Diagnosefindung eine bedeutende Rolle. Besondere Achtsamkeit sollte bei stumpfen Bauchtraumen der oberen Bauchquadranten durch Fahrradlenker, freier Flüssigkeit und starken Abdominalschmerzen geboten sein. Ebenfalls alarmieren sollte eine sonografisch unvollständige Differenzierung oder Diskontinuität der Gallenblasenwand. Bei echoreicher Flüssigkeit im Gallenblasenlumen sollte stets eine intraluminale Blutung in Betracht gezogen werden. Da sich das Bild einer Gallenblasenverletzung oftmals verzögert manifestiert, sind zeitnahe klinische und radiologische Kontrolluntersuchungen unerlässlich.

\section{Kernaussagen:}

- Beim stumpfen, oberen Bauchtrauma sollte eine Gallenblasenverletzung in Betracht gezogen werden.

- Bauchtraumen durch Fahrradlenkerverletzung bedürfen besonderer Achtsamkeit.

- Zeitnahe Wiederholung von klinischen und radiologischen Untersuchungen.

\section{ABSTRACT}

Background Gallbladder perforation is a very rare finding in children. Clinical and radiografic presentations are often vague. Hence it is a challenging diagnosis, often missed during initial evaluation with potentially fatal consequences. The aim of this case report and review was to identify factors that might help to diagnose and manage future cases. 
Methods We present a case of gallbladder perforation in an 8-year-old child after blunt abdominal trauma caused by a handlebar in which imaging modalities such as ultrasound and magnetic resonance imaging (MRI) helped us to determine proper management. We identified and evaluated comparable cases for isolated traumatic gallbladder injury. A review of the recent literature was performed by online search in Pubmed and Google Scholar using "gallbladder injury in children", "gallbladder perforation children”, "blunt abdominal trauma children" as keywords. We focused on articles exclusively in the pediatric section. The literature from the period 2000-2020 was taken into account to review the state of the art in diagnosis and management.

Results and Conclusion Recent literature for gallbladder injury in pediatrics is sparse compared to the adult counterpart. Only eight published cases of isolated gallbladder injury in children were identified. Since the onset of symptoms may not develop acutely and often develops in an indistinct manner, radiografic examinations play an important role in the diagnostic progress. The authors advise caution in cases of blunt abdominal trauma especially involving handlebars, in- traperitoneal free fluid, and severe abdominal pain. We advocate high suspicion of gallbladder perforation if the gallbladder wall displays discontinuation or cannot be definitively differentiated in sonografic examination. Echogenic fluid within the gallbladder should always lead to suspicion of intraluminal bleeding. Repeated clinical and imaging examinations are mandatory since the onset of signs and symptoms may be delayed.

\section{Key Points:}

- Awareness of gallbladder perforation in blunt abdominal trauma of the upper abdomen.

- Particularly high index of suspicion in cases involving handlebar injuries.

- Repeated clinical and imaging examinations are highly recommended.

\section{Citation Format}

- Le MT, Herrmann J, Groth M et al. Traumatic Gallbladder Perforation in Children - Case Report and Review. Fortschr Röntgenstr 2021; 193: 889-897

\section{Introduction}

The abdomen is the third most commonly injured anatomic region followed by the head and extremities [1]. Children are more prone for intraabdominal injuries for several reasons. Firstly, the organs are less protected due to children having less fat and weaker muscles. Secondly, the ribcage offers less protection due to its increased limberness [2]. Furthermore, the smaller body size allows for a greater distribution of injury. Hence, children often suffer multiple traumatic injuries in several regions. Therefore, clinicians must maintain a high index of suspicion in cases of specific injury mechanisms or patterns such as bicycle handlebars in order to detect subtle abdominal injuries. When examining those posttraumatic patients, the possibility of gallbladder perforation must be kept in mind.

We present a case of gallbladder perforation after blunt abdominal trauma in which imaging modalities such as ultrasound and magnetic resonance imaging (MRI) helped us to determine the proper management. Moreover, a systematic review of the recent literature was performed using PubMed and Google Scholar as databases.

\section{Methods}

A review of the literature was performed by online search in PubMed and Google Scholar using "traumatic gallbladder injury in children", "traumatic gallbladder perforation children”, "blunt abdominal trauma children" as keywords. Articles with other extrahepatic biliary injuries as well as other causes of gallbladder perforation such as spontaneous or secondary to an underlying disease were excluded. Furthermore, we searched for cases with isolated traumatic gallbladder injury, comparable to our case. The literature from the period 2000 to 2020 was evaluated.

\section{Case Report}

An 8-year-old male patient was admitted to pediatric emergency for abdominal trauma due to a handlebar injury. The child fell from his bicycle and landed with his upper right abdominal quadrant on the handle of his bike. Physical examination revealed severe upper right abdominal pain, general pale skin color, and a bruise of $3 \mathrm{~cm} \times 3 \mathrm{~cm}$ located in the right upper abdominal quadrant with diffuse abdominal pain on palpated.

Initial Focused Assessment with Sonografy for Trauma (FAST) presented ubiquitous intraperitoneal fluid and irregular reflection of the liver with an inhomogeneous area at the right part. Furthermore, a hyperechogenic structure was pictured at the gallbladder's location. Laboratory analysis unveiled a slight rise in liver enzymes (aspartate aminotransferase (AST): $86 \mathrm{U} / \mathrm{l}$; alanine aminotransferase (ALT): $55 \mathrm{U} / \mathrm{I}$ ) and regular hemoglobin level $(13.1 \mathrm{~g} / \mathrm{dl})$. Considering the trauma, clinical presentation, and sonografic findings, liver laceration and gallbladder hematoma was the presumptive diagnosis.

Because of increasing paleness, hypotension, tachycardia, a 3point drop in hemoglobin, as well as general deterioration and vomiting, abdominal ultrasound was repeated and showed echogenic material in and outside the gallbladder with discontinuation of the wall at the fundus and an increased amount of intraperitoneal fluid, interpreted as progressive intraabdominal hemorrhage ( $\triangleright$ Fig. 1). Emergent magnetic resonance imaging (MRI) followed $\left(\triangleright\right.$ Fig. 2), validating the laceration of the $4^{\text {th }}$ liver segment, the discontinuation of the gallbladder wall, and perihepatic blood pooling adjacent to the gallbladder. With increasing concern re- 

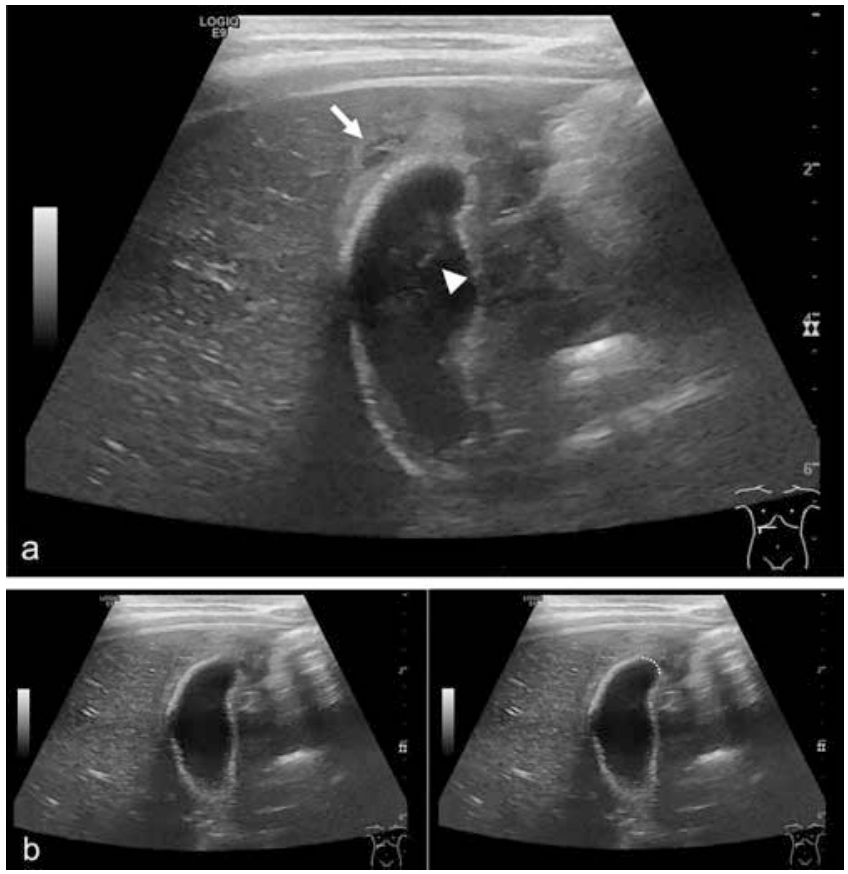

- Fig. 1 B-mode ultrasound images in an 8-year old boy at the level of the gallbladder using a linear transducer (ML6-15). a The arrow marks the small parenchymal laceration in liver segment 4 above the gallbladder. Note the intraluminal echogenic material suggesting hematoma inside the gallbladder (arrowhead). b Left image: A discontinuation of the gallbladder wall can be assumed at the gallbladder fundus. Right image: Same as left image but with schematic drawing: the dashed line (right image) marks the implied discontinuation.

- Abb. 1 B-Mode-Ultraschallbilder eines 8-jährigen Jungen auf Höhe der Gallenblase mittels eines Linearschallkopfes (ML6-15). a Der Pfeil markiert die schmale parenchymatöse Lazeration des 4 Lebersegments über der Gallenblase. Intraluminales, echoreiches Material deutet Hämatom innerhalb der Gallenblase an (Dreieck). b Linke Abbildung: Eine Unterbrechung der Gallenblasenwand im Bereich des Fundus lässt sich erahnen. Rechte Abbildung: Entspricht der linken Abbildung mit zusätzlicher schematischer Darstellung. Die gepunktete Linie markiert die angedeutete, unterbrochene Gallenblasenwand.

garding a gallbladder rupture, laparoscopic exploration was conducted. After extraction of approximately $1.5 \mathrm{I}$ intraperitoneal blood, a perforation $(1.5 \mathrm{~cm} \times 1.5 \mathrm{~cm})$ of the gallbladder fundus with active, pulsatory bleeding could be seen ( $\vee$ Fig. 3 ). Adjacent liver tissue was torn as well. Laparoscopic cholecystectomy and extensive blood staunch management was performed ( $\bullet$ Fig. 4). On the $6^{\text {th }}$ postoperative day, his condition stabilized sufficiently for discharge. A follow-up after four weeks showed full remission. The high-echogenic structure located at the gallbladder's base was no longer visible on abdominal sonografy.

\section{Discussion}

Gallbladder injuries are rare and difficult to diagnose. Injuries of this rather small, hollow organ is reported to be between $1.9 \%$ and $2.1 \%$ of all abdominal traumas and are easily missed during
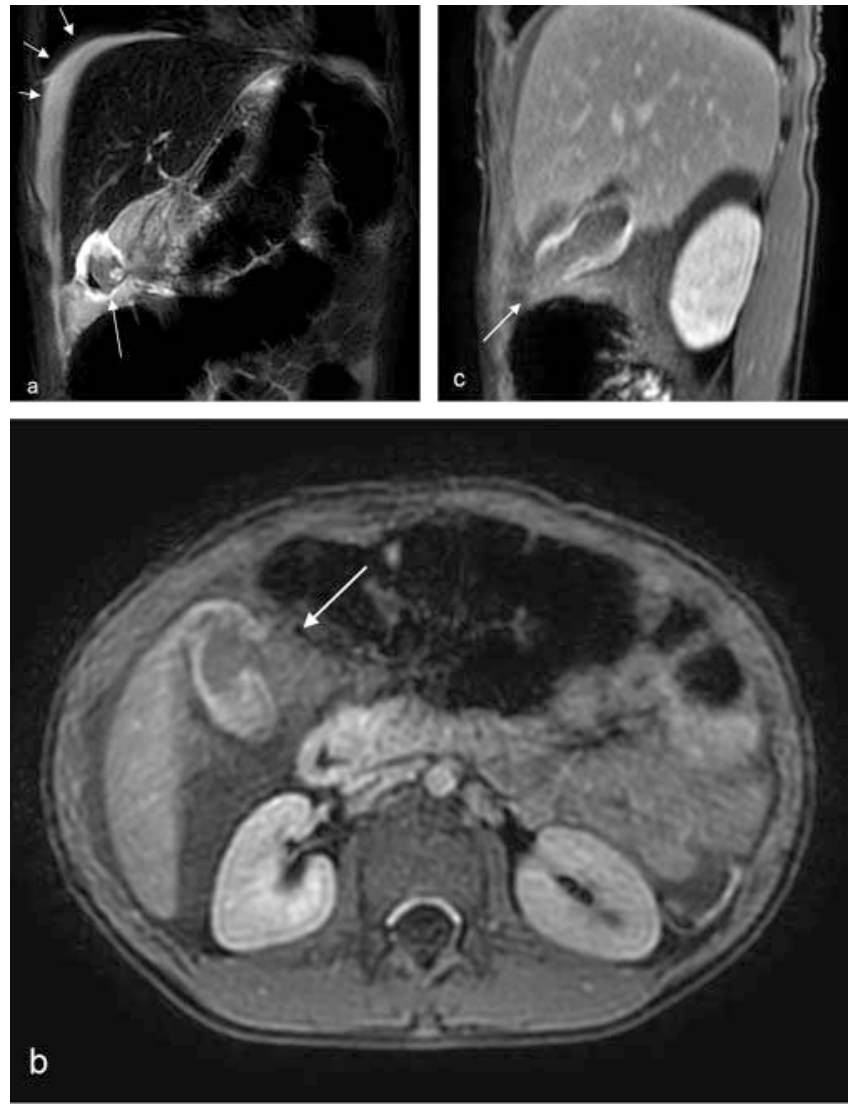

- Fig. 2 MRI of the liver in an 8-year-old boy. Coronal T2fs weighted image a shows hyperintense fluid around the liver (three arrows) and fluid with different signal intensities in the gallbladder bed (single arrow) suggesting hematoma. Transverse $\mathbf{b}$ and sagittal c T1 fs weighted images after i. v. administration of contrast media depict discontinuation of the hyperintense wall at the gallbladder fundus wall (arrow).

- Abb.2 MRT der Leber eines 8-jährigen Jungen. Das koronale, T2fs-gewichtete Bild zeigt Flüssigkeit um die Leber (3 Pfeile) sowie Flüssigkeit mit verschiedenen Signalintensitäten um die Gallenblase (einzelner Pfeil) als Hinweis auf ein Hämatom. Das transversale b und sagittale c T1 fs-gewichtete Bild nach i. v.-Kontrastmittelgabe lässt eine Diskontinuität der hyperintensen Gallenblasenfunduswand erkennen (Pfeil).

initial evaluation $[3,4]$. The most commonly used classification contains contusion, laceration/perforation, and avulsion. [5] Contusion, by definition, is described as the presence of intramural hematoma. Lacerations or perforations are injuries defined as being transmural and are the most commonly reported posttraumatic gall bladder injuries. Avulsive injuries are thought to occur when deceleration forces are applied in the presence of a distended or full gallbladder, as in a postprandial state. [3] In pediatrics, blunt trauma is the most common cause of traumatic gallbladder injury, more specifically road traffic accidents, commonly associated with other visceral injuries. Liver laceration is present in $83 \%$ to $91 \%$ of cases, with duodenal perforation and splenic laceration in up to $50 \%$ [4]. Isolated gall bladder perforation is a very rare occurrence with about $30 \%$ of cases in the pediatric age group [6]. The rare incidence is most likely because of the size and 


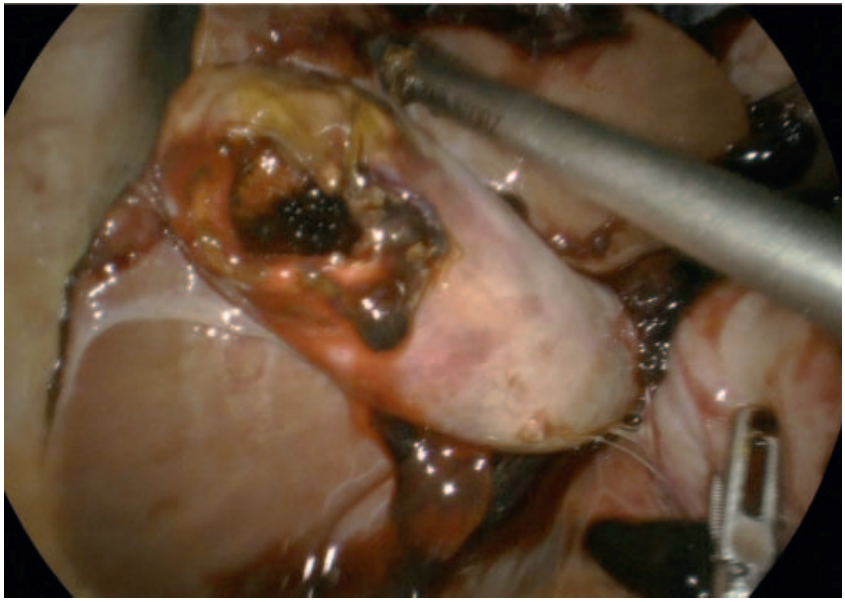

- Fig. 3 Laparoscopic exploration with gallbladder perforation. Exploration revealed a perforation of $1.5 \mathrm{~cm} \times 1.5 \mathrm{~cm}$ of the gallbladder fundus with active, pulsatory bleeding, and massive intraperitoneal blood accumulation.

- Abb. 3 Laparoskopische Exploration bei Gallenblasenperforation. Dargestellt ist eine $1,5 \mathrm{~cm} \times 1,5 \mathrm{~cm}$ große Perforation des Gallenblasenfundus mit aktiver, pulsatorischer Blutung. Sichtbar ist ebenfalls die ausgeprägte intraperitoneale Blutansammlung.

peculiar location of the gallbladder. Lying on the under surface of the liver, it has protection from the ribs and shock absorbance courtesy of the liver [3].

The low prevalence is reflected by the relatively sparse literature for this rare condition. An online literature search for gallbladder injuries in children revealed three original articles for the last two decades $[3,7,8]$, whereas gallbladder injuries for the adult age group are quite well covered. Using PubMed and Google Scholar as databases, only eight published case reports of gallbladder injury in children since 2000 were identified ( $\bullet$ Table $\mathbf{1}$ ) [9-16]. In accordance with the reviewed literature, perforation was the most commonly reported type of gallbladder injury. Only one case presented isolated gallbladder hematoma detected by laparoscopy with conservative treatment [10]. Interestingly, the injury mechanism in this case, described as a fall from the fifth floor of an apartment building, appears to be the most severe one. Despite seemingly harmless trauma mechanisms in the other cases, perforation of the gallbladder was eventually seen: two handlebar injuries, one injury resulting from a fall from a bicycle with no further description, three other abdominal hits by different body parts, and one non-traffic vehicle accident. The common element of all reported cases was the nonspecific and vague clinical presentation on admission. All patient suffered from diffuse abdominal pain and distended or tender abdomen. When the further course of events is depicted, symptoms persisted or increased, similarly to our case. When mentioned, the liver enzymes were either slightly raised or in normal range in primary survey except for in the abovenamed case with isolated gallbladder hematoma (AST/ALT 1073/800 U/I). Free fluid was the most common finding in abdominal sonografic examination. Akay et al. described persistent collapsed gallbladder even after 34 hours of fasting and advocate ultrasound re-evaluation after 6 hours of

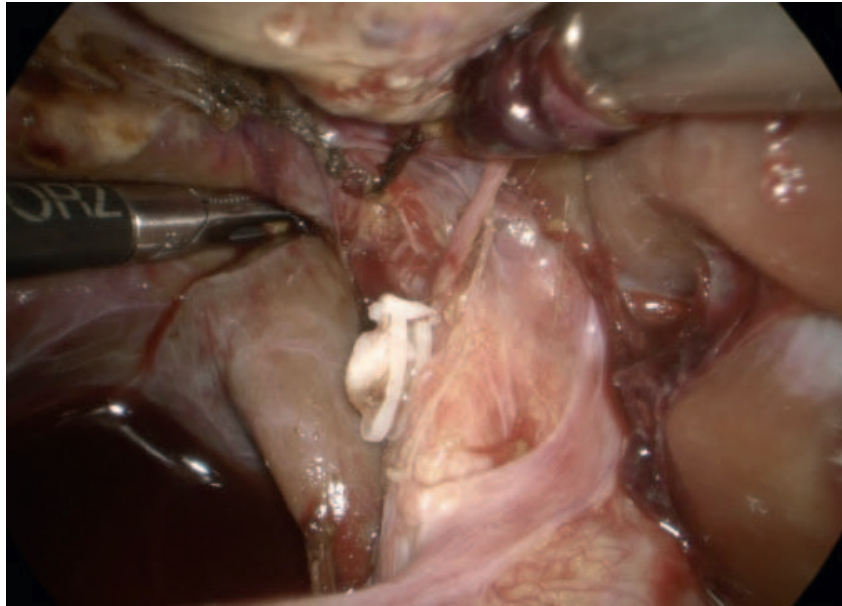

- Fig. 4 Postcholecystectomy. Coagulation measurements by a bipolar electrosurgical device were performed at the gallbladder and adjacent liver tissue since the gallbladder bed was shown to be lacerated and mildly bleeding, as well. After placement of three clips at the cystic duct and coagulation of the arteria cystica, the gallbladder was safely removed without further injury of the liver. Final inspection revealed no further active bleeding.

- Abb.4 Postcholezystektomie. Es erfolgte die lokale Blutstillung mittels elektrischer Koagulation der Gallenblase sowie des Gallenblasenbettes, da sich das angrenzende Lebergewebe ebenfalls leicht blutend zeigte. Nach 3-facher Clippung des Duktus cysticus und Koagulation der Arteria cystica konnte die Gallenblase problemlos ohne zusätzliche Leberverletzung herausgelöst werden. Die abschließende Inspektion zeigte ein blutleeres Resektionsbett.

fasting for the detection of gallbladder perforation [9]. In contrast, in our case the gallbladder was consistently seen to be moderately distended. Our case differs from the others with respect to the aspect that MRI was the advanced imaging modality for definite diagnostic identification. We decided against computed tomografy scanning (CT) to decrease the risk of radiation and malignancy in later life. With the presentation of gallbladder perforation, cholecystectomy was performed in all cases, equally by laparoscopy and laparotomy. The outcome appears to be favorable in all cases. The mean day of discharge was reported on postoperative day 5.5 in laparotomy and 6.3 in laparoscopic intervention. However, these numbers are not representative since two reports with laparoscopic cholecystectomy did not indicate the day of discharge. Besides, one patient with minimally invasive treatment who was discharged on day 11 suffered from multiple extraabdominal injuries, thus prolonging their length of stay [10].

\section{Diagnosis}

With potentially life-threatening advancement, good outcome requires early diagnosis $[7,17]$. The prognosis for isolated injury of the gallbladder remains quite good since mortality is related to associated injuries [18]. However, gallbladder injuries have a vague presentation. Hence, it is a challenging diagnosis that is often incidentally made during laparotomy performed to treat other posttraumatic abdominal lesions [4, 17]. The diagnosis is rarely made preoperatively and is often delayed, since the onset of 


\begin{tabular}{|c|c|c|c|c|c|}
\hline & & 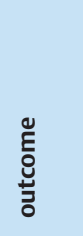 & 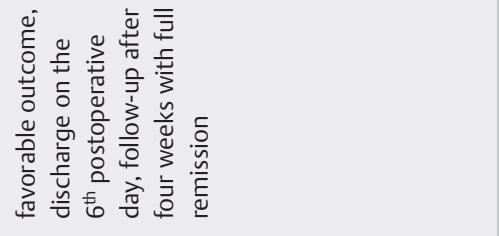 & 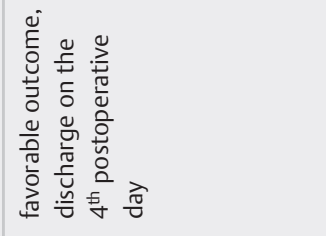 & 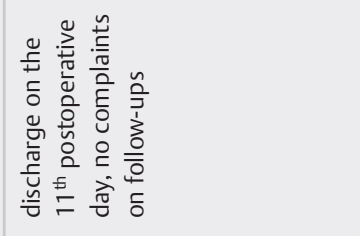 \\
\hline & & 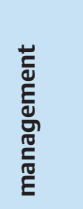 & 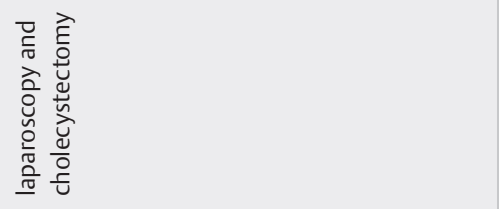 & 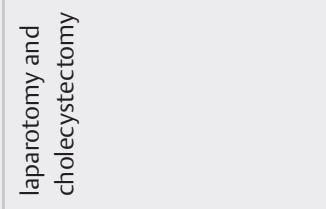 & 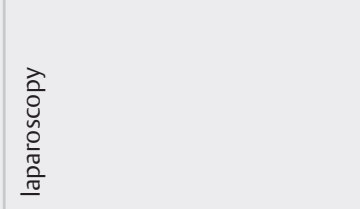 \\
\hline & & 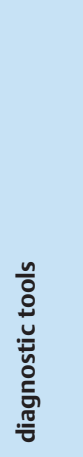 & 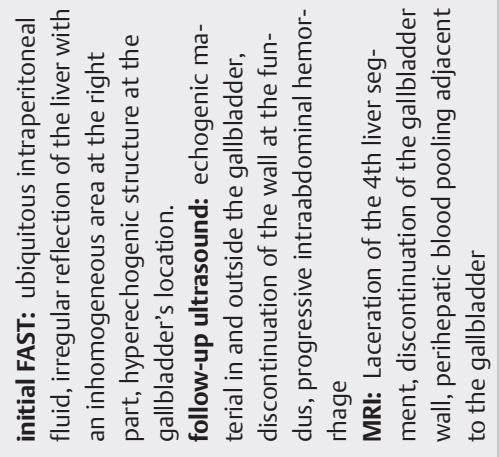 & 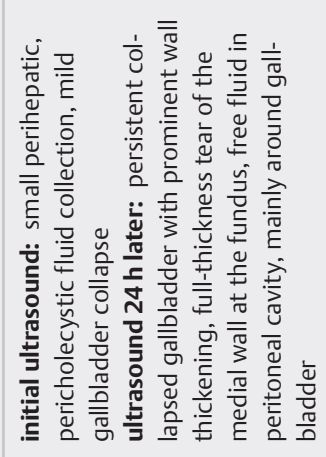 & 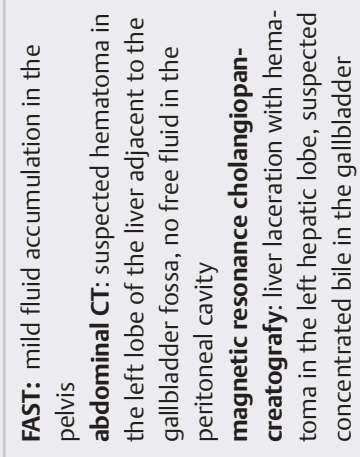 \\
\hline & ¿̊․ & 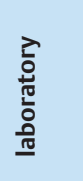 & 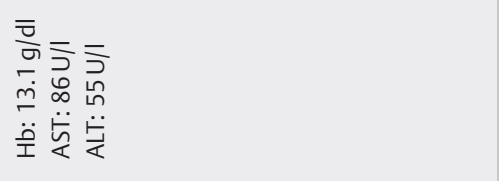 & 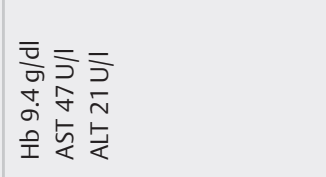 & 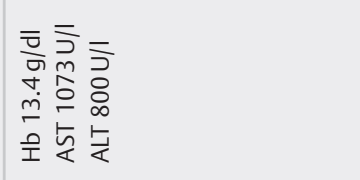 \\
\hline 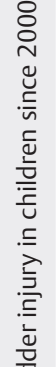 & 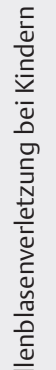 & 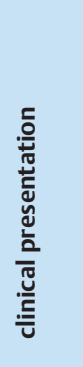 & 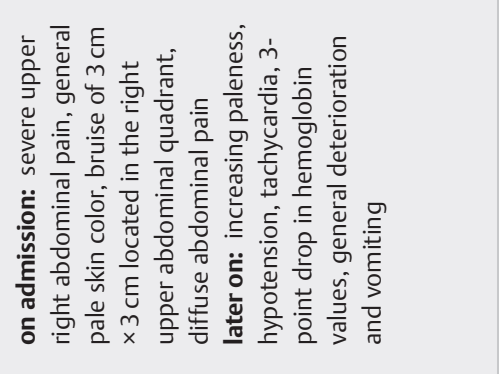 & 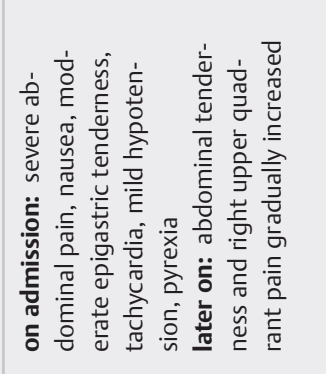 & 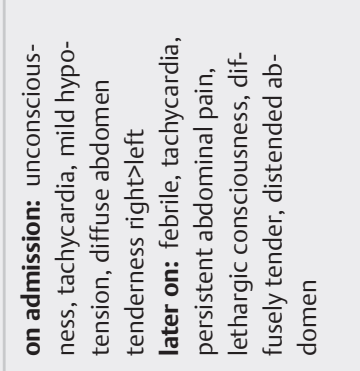 \\
\hline 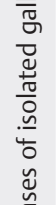 & 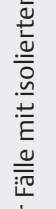 & 惡 & 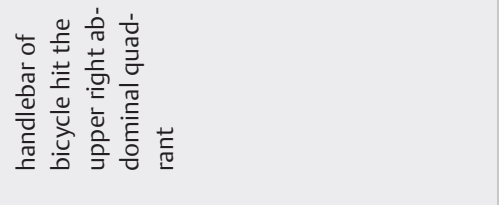 & 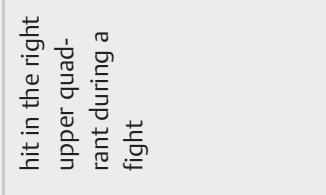 & 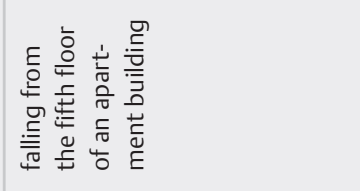 \\
\hline 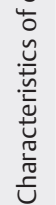 & 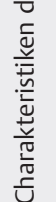 & 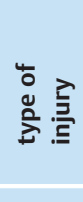 & 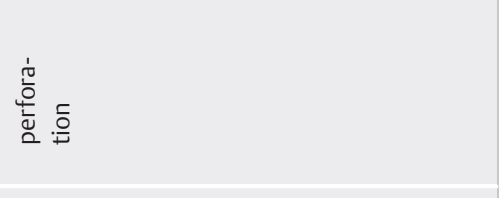 & 离 & 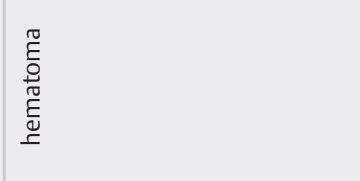 \\
\hline$\frac{\bar{\Xi}}{\frac{0}{\pi}}$ & гே & 总 & 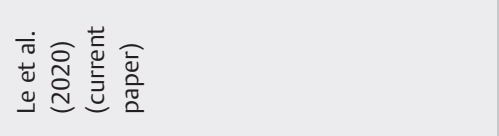 & 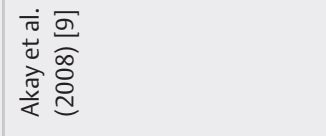 & 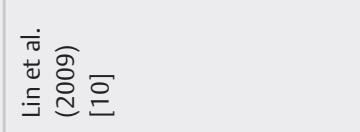 \\
\hline
\end{tabular}




\begin{tabular}{|c|c|c|c|c|}
\hline 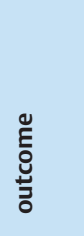 & 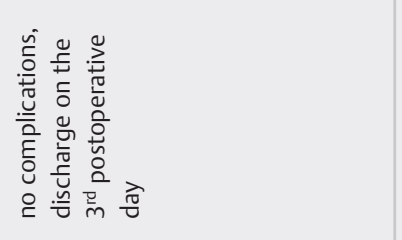 & 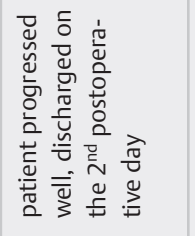 & 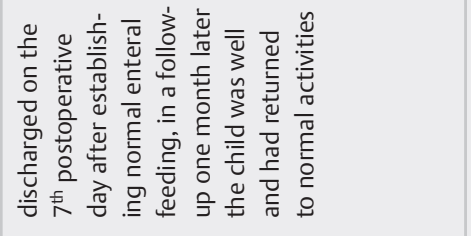 & 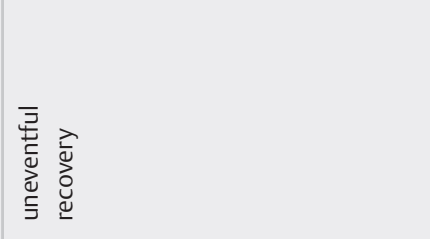 \\
\hline 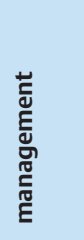 & 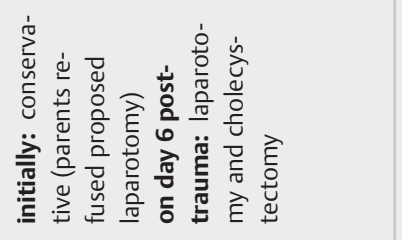 & 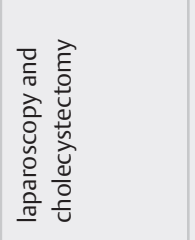 & 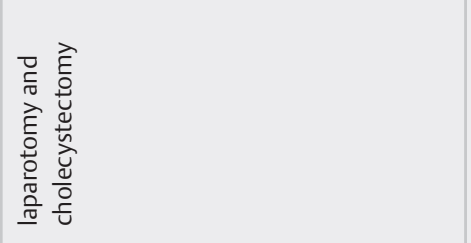 & 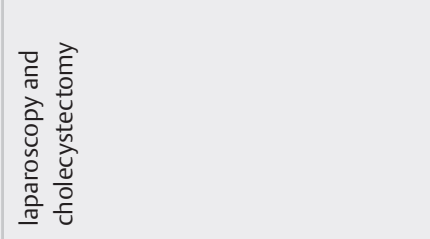 \\
\hline 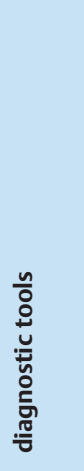 & 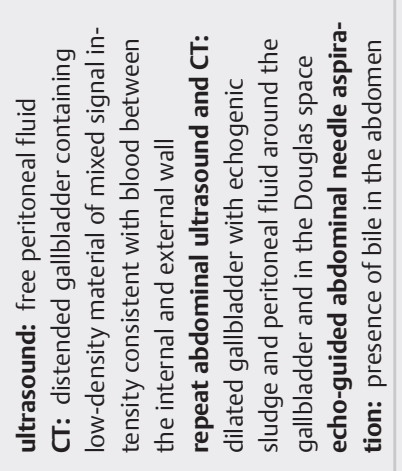 & 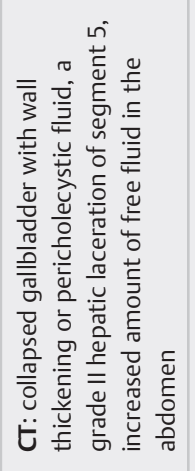 & 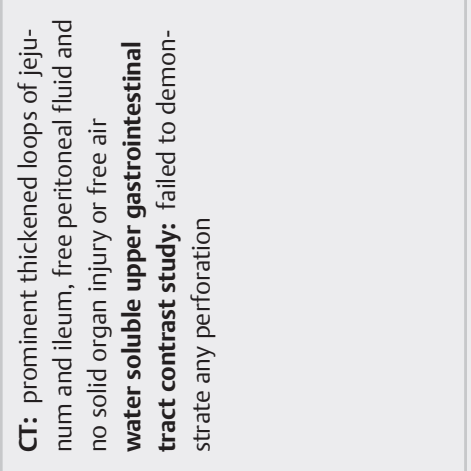 & 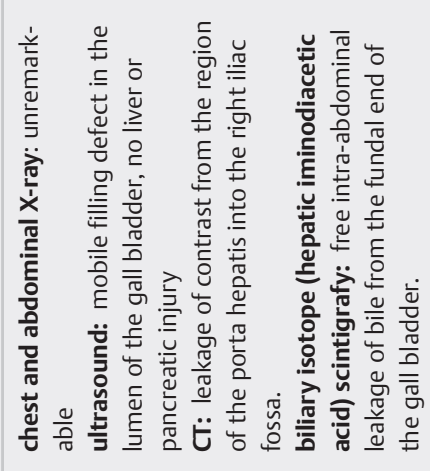 \\
\hline 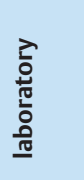 & 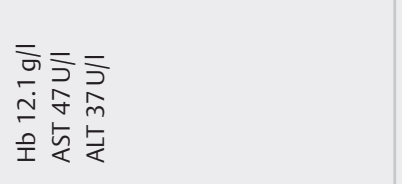 & 1 & 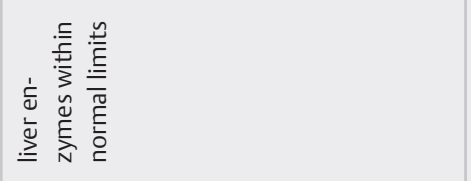 & 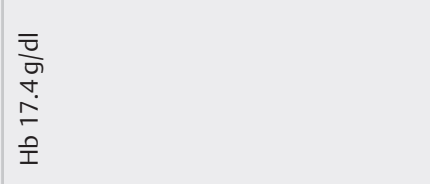 \\
\hline 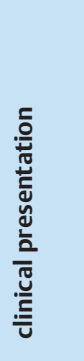 & 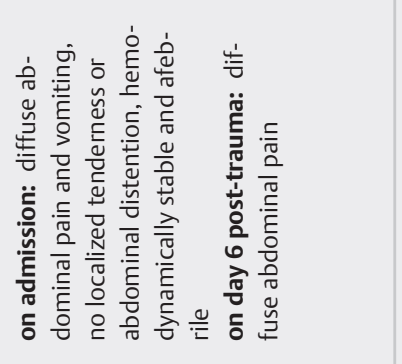 & 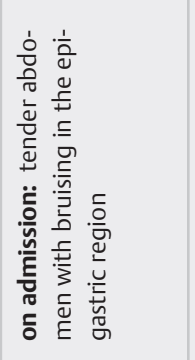 & 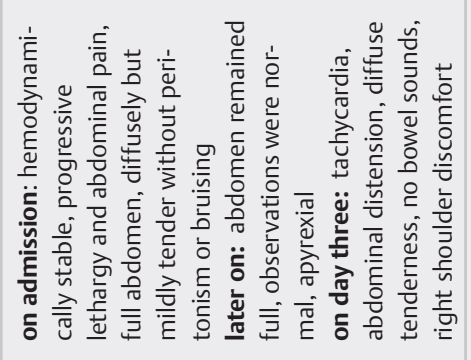 & 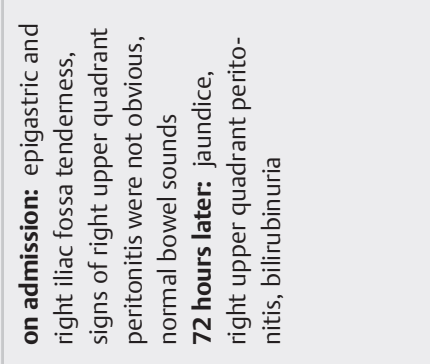 \\
\hline 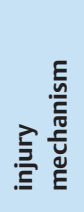 & 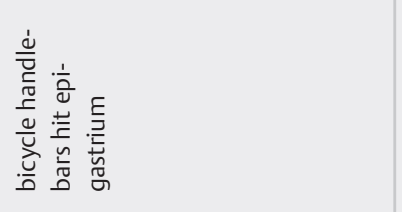 & 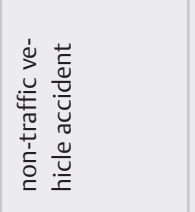 & 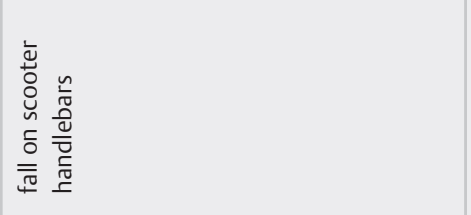 & 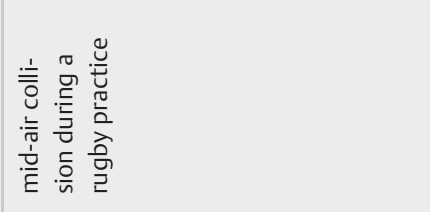 \\
\hline 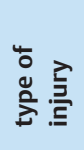 & 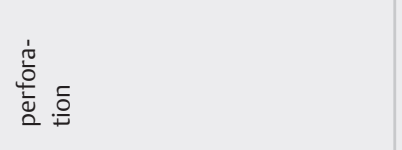 & 苞 & 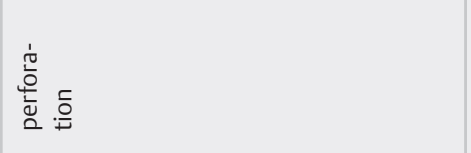 & 悹 \\
\hline 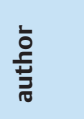 & 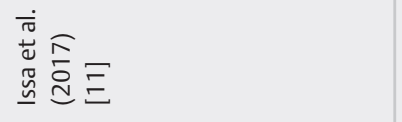 & 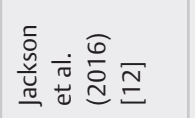 & 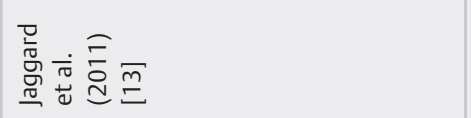 & 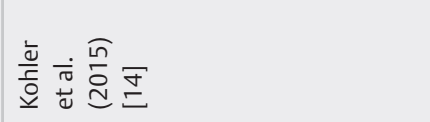 \\
\hline
\end{tabular}




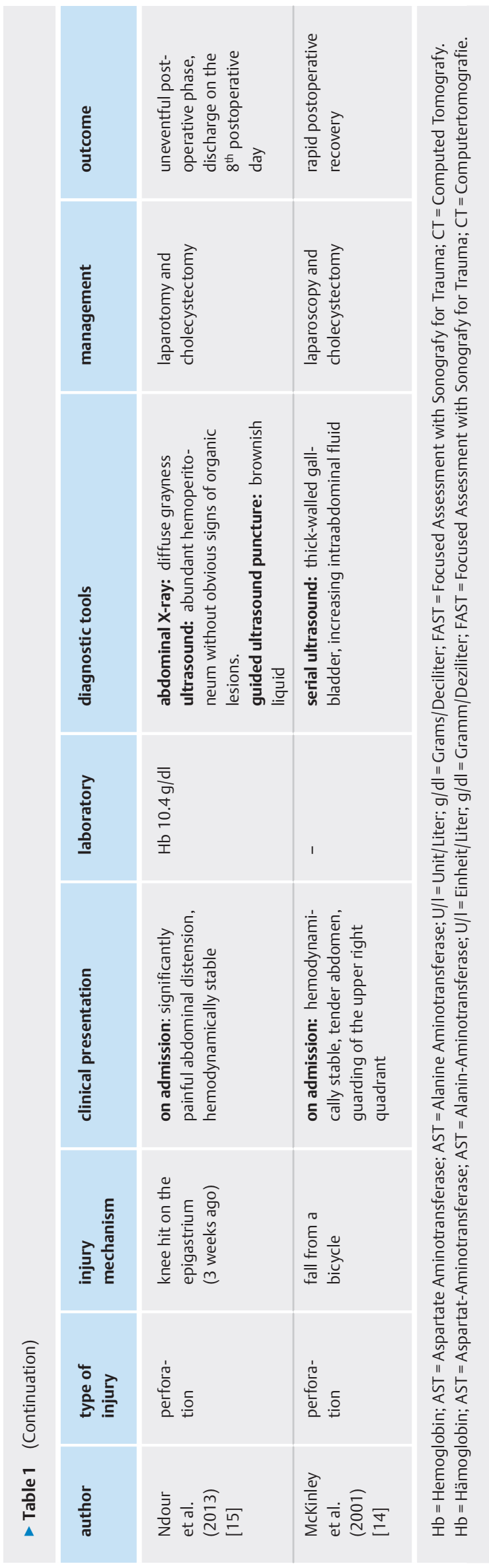

symptoms may not develop acutely. In our case, imaging modalities were the leading diagnostic tool used to make the preoperative diagnosis of liver laceration and gallbladder contusion.

An organized and methodical approach is required in order to identify and manage injuries in trauma patients [1]. As in the adult age group, the examining clinician should apply the algorithm of Advanced Trauma Life Support to assure stable condition for any further diagnostic measurements. The mechanism of trauma provides crucial information on the type of injury. Road traffic accidents remain the most common cause for traumatic gallbladder injury, often handlebar- or seatbelt-related [3, 7]. The morbidity of handlebar injuries is frequently underappreciated, considering that nearly one-third of these patients require surgery [19]. Although this trauma mechanism can occur after seemingly harmless incidents, direct impact on the handlebars may result in more severe injuries than flipping over them [20]. With patients presenting this kind of significant trauma mechanism, clinical and radiologic assessment must dominate. Leading signs and symptoms in our case were severe abdominal pain of the upper-right quadrant, free intraperitoneal fluid, and hemodynamic decompensation, described as hypotension and tachycardia. Diffuse abdominal tensing, suggesting peritonitis due to hemoperitoneum or perforation, may not always be observable.

With ultrasound being rapid, inexpensive, portable, and readily repeatable, this noninvasive imaging modality is well suited as the initial diagnostic tool to determine further management and diagnosis. Sonografic examination even allows imaging of the gallbladder contusion defined as intramural hemorrhage. A thickened wall can be presented. This kind of injury probably occurs more commonly than previously reported [3]. All in all, the findings of gallbladder perforation are non-specific in most cases: pericholecystic fluid collection, thickened or discontinuous gallbladder wall, collapsed gallbladder, and intraluminal echogenic debris due to hematoma can be seen [17]. FAST can detect the presence of free fluid suggestive of intraabdominal injury. In pediatrics, the utility of FAST can be limited since less than half of children (<40\%) with abdominal injury present free intraperitoneal fluid. Hence, the lack of intraperitoneal fluid should not lead to premature dismissal of intraabdominal injury $[1,21]$. Nonetheless, sonografic examination first identified gallbladder injury in our case. Additional to the increasing intraperitoneal fluid, the gallbladder wall could not be differentiated at the fundus. Hematoma was found to be adjacent. We advocate high suspicion of gallbladder perforation if the gallbladder wall displays discontinuity or cannot be definitively differentiated. In blunt abdominal trauma, echogenic fluid within the gallbladder should always lead to suspicion of bleeding into the lumen [22].

In children and adults alike, CT is the preferred imaging modality in severe abdominal trauma $[3,12,23]$ and the most common modality for detecting gallbladder injury [24, 25]. The presence of pericholecystic fluid strongly suggests injury to the gallbladder [26]. However, the overuse of CT in stable, minimally injured children is an important area of concern that differs from adult trauma protocols and remains highly debated in emergency situations. Mahajan et al. claim that clinicians often obtain abdominal CT scans in patients that are considered very low risk of injury [27]. A study including 20667 pediatric trauma patients revealed 
that children managed at adult trauma centers were 1.8 times more likely to receive whole-body CT imaging with the associated increased risk of radiation without a difference in clinical outcomes [28]. MRI can be used as an evaluative tool without hazardous ionization, giving additional diagnostic benefit in terms of tissue imaging. In cases of intraabdominal fluids, it has a particular role in revealing the underlying pathology. [3] In children with mild trauma who are clinically stable, imaging without radiation exposure should be preferred to minimize the risk of subsequent malignancy [29]. Presently, MRI is not established in the setting of acute abdominal trauma in most centers. With newer, less timeconsuming protocols, emergent MRI has the potential to achieve more acknowledgement.

More recently, contrast-enhanced ultrasound (CEUS) has been developed with a diagnostic accuracy for detecting solid organ injuries comparable to that of CT. [30] As stated above, it is not always possible to rule out the presence of parenchymal traumatic lesions by sonografic examination since free intraperitoneal fluid is not always present [21]. CEUS, using second-generation contrast agents which remain intravascular, has the capability of providing a more detailed description of lesion size, the extension to the solid organ capsule, and the presence of vascular injuries [30]. A solid organ injury is unveiled as a perfusion defect. Lacerations are visualized as a hypoechoic area with an irregular border and can be associated with capsular discontinuity. Given the contrast agents attributes, active bleeding of the gallbladder can be detected as extravasation of hyperechoic bubbles into the peritoneal space [31]. The visualization of the hyperechoic microbubbles within the gallbladder wall allow a more accurate visualization of the gallbladder wall, ultimately resulting in higher certainty in the identification of discontinuity or rupture. Since the contrast agent is breathed out by the lungs (laboratory testing prior to examination (i. e. kidney function) not required) and there is no ionizing radiation, CEUS is much more suited for initial examination as well as for follow-ups in trauma with conservative management in the pediatric patient [31]. However, the second-generation contrast agents are still off-label in children although several multi-centric studies have already demonstrated safety in pediatric populations [32, 33].

Gallbladder perforations frequently cause increased hepatic enzymes, particularly the transaminases. Nonetheless, the usefulness of elevated transaminases to predict clinically significant liver injury as a potential screening tool for imaging is debatable. Several cut-off values for liver injury have been introduced in the literature. With AST/ALT levels at 86/55 U/I during the first evaluation and 176/135 U/I approximately 20 hours later, the transaminase levels of our patient never exceeded the commonly used cut-off values for liver injury. The same applies to most of the other case reports. However, lowering the thresholds of AST/ALT guidelines could lead to unnecessary CT scans for children [36]. Since normal transaminase levels do not exclude gallbladder injury, the general usefulness of laboratory testing is limited. Although anemia is an obvious predictor of hemorrhage, hemoglobin and hematocrit levels were found to be normal during primary survey in our case. Initial testing of hemoglobin and hematocrit is recommended in the evaluation of patients with pediatric abdom- inal trauma, but is not a good indicator of the need for additional imaging studies [20].

All in all, the leading indications which finally led us to proper diagnosis were clinical presentation and imaging modalities, with special emphasis on ultrasound. In our case, persistent abdominal pain after blunt trauma and significant deterioration of general condition raised concerns regarding intraabdominal injuries. UItrasound examination right from the beginning of the diagnostic process and the repeated follow-up in a short interval was able to detect progressive intraabdominal hemorrhage. Concerns for a gallbladder injury were unveiled by sonografic imaging, initially interpreted as gallbladder contusion with rising suspicion for laceration/perforation in the further course. Emergency MRI provided the final confirmation which led us to explorative laparoscopy; the discontinuation of the hyperintense gallbladder wall and intraluminal accumulation of not only fluid but also blood with massive intraperitoneal ascites suggesting perforation of the gallbladder with high suspicion of bile leakage.

\section{Management}

Instead of surgical intervention, close observation of the patient is sufficient in most patients. Simple contusions or partial avulsions may be treated conservatively. The hemodynamic condition of the child is the most important factor [20]. A surgeon must be readily available in case the patient becomes hemodynamically unstable and requires immediate surgical intervention. Serial physical examinations and sequential monitoring of general condition and hemodynamic stability are of highest importance [6, 7]. Advanced imaging modalities have reduced the necessity for laparotomy to less than $10 \%$ following blunt abdominal trauma in children [2, 37] and has enormously contributed to the shift from operative to non-operative management [2, 7]. Free intraperitoneal fluid does not absolutely necessitate surgery. In case of low energy and negligible volume, careful serial observation and imaging are a reasonable approach. Diagnostic laparoscopy is advised in all other cases [3] and is an excellent modality for the investigation with the benefit of simultaneous minimally invasive treatment options. In terms of severe contusion or avulsion and perforation of the gallbladder, the definitive procedure of choice is laparoscopic cholecystectomy $[4,18,25]$.

\section{Conclusion}

The authors advocate caution in cases of blunt abdominal trauma with intraperitoneal free fluid and severe abdominal pain. We advise high suspicion of gallbladder perforation if the gallbladder wall displays discontinuation or cannot be definitively differentiated in sonografic examination. Echogenic fluid within the gallbladder should always lead to suspicion of intraluminal bleeding. MRI is a useful diagnostic tool for the identification and closer examination of intraabdominal injuries without the use of hazardous ionization. We highly advocate MRI as a potential alternative to CT in the setting of acute abdominal trauma, especially in the pediatric field. Pericholecystic fluid is a common finding in advanced imaging modalities for gallbladder injury. Repeated clinical and 
imaging examinations are mandatory since the onset of signs and symptoms may be delayed.

\section{Conflict of Interest}

The authors declare that they have no conflict of interest.

\section{References}

[1] Lynch T, Kilgar ], Al Shibli A. Pediatric Abdominal Trauma. Curr Pediatr Rev 2018; 14: 59-63

[2] Miele V, Piccolo CL, Trinci M et al. Diagnostic imaging of blunt abdominal trauma in pediatric patients. Radiol Med 2016; 121: 409-430

[3] Jaggard MK], Johal NS, Choudhry M. Blunt abdominal trauma resulting in gallbladder injury: a review with emphasis on pediatrics. J Trauma 2011; 70: 1005-1010

[4] Soderstrom CA, Maekawa K, DuPriest RW et al. Gallbladder injuries resulting from blunt abdominal trauma: an experience and review. Ann Surg 1981; 193: 60-66

[5] Smith SW, Hastings TN. Traumatic rupture of the gallbladder. Ann Surg 1954; 139: 517-520

[6] Schachter P, Czerniak A, Shemesh E et al. Isolated gallbladder rupture due to blunt abdominal trauma. HPB Surg 1989; 1: 359-362

[7] Galifer RB, Forgues D, Mourregot A et al. Blunt traumatic injuries of the gastrointestinal and biliary tract in childhood. Analysis of 16 cases. European journal of pediatric surgery: official journal of Austrian Association of Pediatric Surgery 2001; 11: 230-234

[8] Gupta A, Stuhlfaut JW, Fleming KW et al. Blunt trauma of the pancreas and biliary tract: a multimodality imaging approach to diagnosis. Radiografics 2004; 24: 1381-1395

[9] Akay HO, Senturk S, Cigdem MK et al. Isolated traumatic gallbladder rupture: US findings and the role of repeat US in diagnosis. Pediatr Radiol 2008; 38: 691-693

[10] Hsing-Lin L, Jiun-Nong L, Wei-Che L et al. Blunt Abdominal Injury With Isolated Gallbladder Hematoma. Tzu Chi Med Journal 2009; 21: 323326

[11] Issa I, Modica Alameddine V, Fadous Khalife MC et al. Isolated and stable gallbladder perforation in a 5 year old child after blunt abdominal trauma. Trauma Case Rep 2017; 9: 27-29

[12] Jackson WL, Bonasso PC, Maxson RT. Pediatric traumatic gallbladder rupture. J Surg Case Rep 2016; 12: 1-2

[13] Jaggard MKJ, Johal N, Haddad M et al. Isolated gallbladder perforation following blunt abdominal trauma in a six-year-old child. Ann R Coll Surg Engl 2011; 93: e29-e31

[14] Kohler R, Millin R, Bonner B et al. Laparoscopic treatment of an isolated gallbladder rupture following blunt abdominal trauma in a schoolboy rugby player. Br J Sports Med 2002; 36: 378-379; discussion 379

[15] Ndour O, Moustapha H, Ndoye NA et al. Isolated gallbladder perforation after blunt abdominal trauma in children. Afr J Paediatr Surg 2013; 10: $41-42$

[16] McKinley AJ, Mahomed AA. Laparoscopy in a case of pediatric blunt abdominal trauma. Surg Endosc 2002; 16: 358

[17] Hongo M, Ishida $\mathrm{H}$, Naganuma $\mathrm{H}$ et al. A case of gallbladder perforation detected by sonografy after a blunt abdominal trauma. J Clin Ultrasound 2014; 42: 301-304
[18] Sharma O. Blunt gallbladder injuries: presentation of twenty-two cases with review of the literature. J Trauma 1995; 39: 576-580

[19] Nadler EP, Potoka DA, Shultz BL et al. The high morbidity associated with handlebar injuries in children. J Trauma 2005; 58: 1171-1174

[20] Wegner S, Colletti JE, van Wie D. Pediatric blunt abdominal trauma. Pediatr Clin North Am 2006; 53: 243-256

[21] Emery KH, McAneney CM, Racadio JM et al. Absent peritoneal fluid on screening trauma ultrasonografy in children: a prospective comparison with computed tomografy. J Pediatr Surg 2001; 36: 565-569

[22] Kauzlaric D, Barmeir E. Sonografy of intraluminal gallbladder hematoma. J Clin Ultrasound 1985; 13: 291-294

[23] Sivit Cl. Contemporary imaging in abdominal emergencies. Pediatr Radiol 2008; 38 (Suppl. 4): S675-S678

[24] Kwan BYM, Plantinga P, Ross I. Isolated traumatic rupture of the gallbladder. Radiol Case Rep 2015; 10: 1029

[25] Egawa N, Ueda J, Hiraki M et al. Traumatic Gallbladder Rupture Treated by Laparoscopic Cholecystectomy. Case Rep Gastroenterol 2016; 10: 212-217

[26] Erb RE, Mirvis SE, Shanmuganathan K. Gallbladder injury secondary to blunt trauma: CT findings. J Comput Assist Tomogr 1994; 18: 778-784

[27] Mahajan P, Kuppermann N, Tunik M et al. Comparison of Clinician Suspicion Versus a Clinical Prediction Rule in Identifying Children at Risk for Intra-abdominal Injuries After Blunt Torso Trauma. Acad Emerg Med 2015; 22: 1034-1041

[28] Pandit V, Michailidou M, Rhee P et al. The use of whole body computed tomografy scans in pediatric trauma patients: Are there differences among adults and pediatric centers? J Pediatr Surg 2016; 51: 649-653

[29] Drexel S, Azarow K, Jafri MA. Abdominal Trauma Evaluation for the Pediatric Surgeon. Surg Clin North Am 2017; 97: 59-74

[30] Valentino M, Serra C, Pavlica P et al. Blunt abdominal trauma: diagnostic performance of contrast-enhanced US in children-initial experience. Radiology 2008; 246: 903-909

[31] Miele V, Piccolo CL, Galluzzo M et al. Contrast-enhanced ultrasound (CEUS) in blunt abdominal trauma. Br J Radiol 2016; 89: 20150823

[32] Trinci M, Piccolo CL, Ferrari R et al. Contrast-enhanced ultrasound (CEUS) in pediatric blunt abdominal trauma. J Ultrasound 2019; 22: 27-40

[33] Menichini G, Sessa B, Trinci M et al. Accuracy of contrast-enhanced ultrasound (CEUS) in the identification and characterization of traumatic solid organ lesions in children: a retrospective comparison with baseline US and CE-MDCT. Radiol Med 2015; 120: 989-1001. Available from: URL: https://pubmed.ncbi.nlm.nih.gov/25822953/

[34] Karam O, La Scala G, Le Coultre C et al. Liver function tests in children with blunt abdominal traumas. European journal of pediatric surgery: official journal of Austrian Association of Pediatric Surgery 2007; 17: 313-316

[35] Hennes HM, Smith DS, Schneider K et al. Elevated liver transaminase levels in children with blunt abdominal trauma: a predictor of liver injury. Pediatrics 1990; 86: 87-90

[36] Zagory JA, Dossa A, Golden J et al. Re-evaluation of liver transaminase cutoff for $\mathrm{CT}$ after pediatric blunt abdominal trauma. Pediatr Surg Int 2017; 33: 311-316

[37] Ameh EA, Chirdan LB, Nmadu PT. Blunt abdominal trauma in children: epidemiology, management, and management problems in a developing country. Pediatr Surg Int 2000; 16: 505-509 